\title{
Hairy cell leukaemia and occupational exposure to benzene
}

\author{
J Clavel, F Conso, J-C Limasset, L Mandereau, P Roche, G Flandrin, D Hémon
}

\begin{abstract}
Objectives-The role of occupational exposures in hairy cell leukaemia (HCL) was investigated through a multicentre, hospital based, case-control study. This paper analyses the role of exposure to benzene in HCL.

Methods-A population of 226 male cases of HCL and 425 matched controls were included in the study. Benzene exposure was evaluated by expert review of the detailed data on occupational exposures generated by case-control interviews.
\end{abstract}

Results-No association was found between HCL and employment in a job exposed to benzene (odds ratio (OR) 0.9 (95\% confidence interval (95\% CI) $0 \cdot 6-1 \cdot 3)$ ). The sample included 125 subjects, 34 cases $(15 \%)$, and 91 controls (21\%) who had been exposed to benzene, as individually assessed by the experts, for at least one hour a month during one of their jobs. Benzene exposure was not associated with a risk of HCL (OR 0.8 $(0 \cdot 5-1 \cdot 2))$. No trend towards an increase in OR was detected for increasing exposures, the percentage of work time involving exposure to $>1 \mathrm{ppm}$, or the duration of exposure. No findings suggested a particular risk period, when the $\mathrm{OR}$ associated with the time since first or last exposure, or since the end of exposure, were examined.

Conclusions-In conclusion, with the low exposures prevalent in the sample, the study did not show any association between benzene exposure and HCL.

(Occup Environ Med 1996;53:533-539)

Keywords: case-control study; leukaemia hairy cell; benzene

Service de patho

Hôpital Cochin, Paris,

France

F Conso

Institut National de

Recherche et de

Sécurité, Nancy,

France

J-C Limasset

Laboratoire Central

d'Hématologie,

Hôpital Necker, Paris,

France

G Flandrin

Correspondence to:

Dr J Clavel, INSERM U

170,16 Avenue Paul

Vaillant-Couturier, 94807

Villejuif Cedex, France.

Accepted 21 February 1996 benzene have been very widely used, particularly as starting materials for numerous chemical syntheses, as diluents for inks, paints, and adhesives, and as degreasing agents. Particularly high exposures have occurred in the footwear, chemical, rubber, and printing industries. The petrol currently used as vehicle fuel contains $1 \%-5 \%$ benzene, giving rise to lower exposures, but exposure is very frequent in the general population.

Benzene has been clearly shown to play a causal part in leukaemia, on the basis of both experimental and epidemiological evidence. ${ }^{1}$ The epidemiological data supporting the conclusion that benzene is carcinogenic in man were generated in working environments in which exposures were particularly high. ${ }^{2-6}$ The risk is much more obvious for acute myeloid leukaemias. The survey conducted on 1006 members of the personnel of Pliofilm, a United States rubber manufacturing corporation, between 1940 and 1959, strongly contributed to establishing the leukaemogenic effect of benzene. ${ }^{4-6}$ A very clear relation between exposure and risk was found with cumulative exposure. ${ }^{6}$ Extrapolation of this relation to estimate the risk associated with low doses has been the subject of controversy. ${ }^{78}$ No case of chronic lymphoid leukaemia (CLL) was found in this cohort, but there were four cases of multiple myeloma, three of which occurred more than 20 years after the start of exposure. The exposures were lower in these multiple myelomas and an exposure response gradient was not present.

One study has detected a high risk of CLL in subjects also exposed to solvents other than benzene in the rubber industry. ${ }^{9}$ Case-control studies conducted in one of the corporations included in the cohort showed a relation between CLL and solvents other than benzene, particularly carbon tetrachloride, carbon disulphide, and acetone. ${ }^{1011}$

The studies conducted in several countries in oil refineries and service stations, sectors in which the level of exposure to benzene is generally low, do not enable the possibility of a moderate increase in the risk of leukaemia to be discounted. ${ }^{12-15}$ No HCL was found in these cohort studies. In the study by Oleske et $a l,{ }^{16}$ which included 45 cases of HCL and 134 controls, professional exposure to an organic chemical for at least two years was associated with an odds ratio (OR) (95\% confidence interval $(95 \% \mathrm{CI})$ ) of $3 \cdot 1(1 \cdot 5-6 \cdot 4)$. In the study by Staines and Cartwright, ${ }^{17}$ which included 50 cases of HCL and 95 controls, exposure to petroleum products (all products taken together) was associated with an OR of $2 \cdot 1(0 \cdot 9-5 \cdot 0)$ and exposure to benzene with an OR of $2 \cdot 0(0 \cdot 5-8 \cdot 0)$. Flandrin and Collado 
investigated a large series of cases and suggested that the male predominance of the disease could be related to environmental factors, especially to benzene and ionising radiation. ${ }^{18}$

The present study investigates the relation between HCL and occupational benzene exposure in a large sample (226 male HCL cases and 425 matched controls) for which exposure was assessed by expert review of specific interview data on a case by case basis.

\section{Subjects and methods}

SELECTION OF CASES AND CONTROLS

Retrospective recruitment of cases and controls was conducted in 18 hospitals spread through most of France (Angers, Bayonne, Bordeaux, Caen, Chambéry, Lille, Limoges, Lyon, Nancy, Nantes, Nice, Nimes, Paris, Poitiers, Rennes, Rouen, Strasbourg, Toulouse). All the cases, including dead cases, diagnosed from January 1980 to January 1990 , were identified and recorded, but data were only obtained from the survivors. All diagnoses were histologically confirmed.

The controls were selected from contemporary inpatients, mainly in orthopaedic and rheumatological departments, from the admission lists for the 10 year period. The choice of the source departments for controls was mainly governed by the practical need to target the same age bracket as that of the cases, without preferentially selecting certain diseases (especially those related to occupational exposures, smoking, or alcohol consumption), habits, or socioeconomic status, and by the need to concentrate retrospective sampling on a restricted number of admission records in each city. Subjects admitted for malignant disease, disease related to occupation, or work accidents were not eligible as controls. Controls were individually matched with each case on the basis of sex, birth date ( \pm 3 years), admission date ( \pm 3 years) and residence (inside or outside the administrative area-département - in which the hospital was located). An attempt was made to match two controls with each case.

The cases and controls were sent a questionnaire designed for self administration. Nonresponders were sent the questionnaire at most two more times. If a control had not responded after three requests to do so, he was replaced by another control from the list, with the same selection criteria.

In all, 378 male cases were identified from the records of 18 haematology departments. From these, 226 living cases (60\%) were included. Out of the 152 cases excluded, 100 had died ( 68 before 1984), and 52 did not return the questionnaire. A total of 809 men were eligible as controls and were sent the questionnaire. The completed questionnaire was returned by 465 potential controls $(57 \%)$. Forty responders had to be excluded because their individually matched cases were dead or non-responders and because they could not be matched with other cases. A total of 425 male controls were thus finally included. Table 1 shows the distribution of the reasons for admission to hospital.
Table 1 Reasons for admission to hospital of the controls

\begin{tabular}{lc}
\hline & $\begin{array}{l}\text { Men } \\
n(\%)\end{array}$ \\
\hline Rheumatological diseases & $166(39 \cdot 1)$ \\
Injuries & $124(29 \cdot 2)$ \\
Urological diseases & $25(5 \cdot 9)$ \\
Osteopathies & $21(4 \cdot 9)$ \\
Benign tumours (lipomas) & $15(3 \cdot 5)$ \\
Neurological diseases & $13(3 \cdot 1)$ \\
Cardiovascular diseases & $12(2 \cdot 8)$ \\
Infectious diseases & $8(1 \cdot 9)$ \\
Respiratory diseases & $7(1 \cdot 6)$ \\
Others & $22(5 \cdot 2)$ \\
Unknown & $12(2 \cdot 8)$ \\
Total & $425(100)$ \\
\hline
\end{tabular}

Finally, $30 \%$ of the cases were matched with a single control, $56 \%$ with two controls, and $14 \%$ with three to five controls.

\section{DATA COLLECTION}

The self administered questionnaires included questions on sociodemographic characteristics, tobacco smoking, lifelong occupations, and leisure activities. Complementary questionnaires were given to subjects when professional exposure to organic solvents was suspected. The interviews were conducted by telephone, by occupational health physicians who received specialised training. Both the patients and interviewers were blind to the hypotheses underlying the study.

Specific semistructured questionnaires were designed to allow the experts to conduct case by case reviews to assess solvent exposure. The questionnaires included both open questions to elicit description of the workplace and closed questions to define the tasks accomplished, products handled, and working conditions. Specialised questionnaires were used for garage workers (mechanical maintenance and body work repair tasks), for the exposures of machine tool operators, fitters, mechanics who degreased metal parts, for all other jobs involving degreasing (glass, textiles, etc), for professions involving the use of paints or adhesives, and for workers in the printing industry. For workers in laboratories and the chemical industry the interview simply covered a detailed description of the work station, products used, and working conditions, and no specific questionnaire was given.

\section{EXPOSURE DEFINITION}

Before the study, the experts, two of the authors with extensive experience in industrial health and hygiene (FC and JCL), compiled a list of the jobs liable to involve exposure to benzene. Jobs were coded with International Labour Office nomenclature ${ }^{19}$ and industrial sectors were coded with international standard industrial classification (ISIC) nomenclature. ${ }^{20}$ Only jobs lasting at least six months were considered.

Also, the experts, blind to case-control status, conducted a case by case assessment of exposure to benzene. They reviewed the consistency of the subjects' statements for calendar period, type of industry, job title, and type of exposure. An effort was made to assess benzene exposure and to standardise the expert process. ${ }^{21}$ As very different scales-for 
example, linear or exponential-may be classified in terms of low, moderate, and high exposures, an attempt was made to obtain a score that parallelled atmospheric concentrations (ppm). Benzene exposures were evaluated first within job categories then across these categories to facilitate the classification of exposures to pure benzene, petrol, and nondearomatised mineral spirit between jobs.

From published data, ${ }^{152-26}$ and the levels tolerated at various times, a probable exposure was estimated for each of the tasks targeted in the questionnaire and the scores were expressed in "ppm". The quote marks are used deliberately, as "ppm" denotes a score and not the result of a quantitative measurement of concentration. The overall for a given job was calculated as the weekly cumulative exposure for the various tasks divided by 40 hours, as the time weighted average (TWA) is a standard reference value in industrial hygiene.

Several lifelong exposure variables were constructed. A dichotomous exposure variable was defined as handling benzene or a product containing benzene for at least an hour a month in any one job held for at least six months. The TWA exposure was calculated for each job from the "ppm" score estimated for each task. Lifelong exposure was then estimated with three indices: (a) maximum exposure-that is, the level in the most exposed job in the subject's working history; (b) cumulative exposure - that is, the sum of the products of job exposure levels and job durations; (c) mean exposure - that is, cumulative exposure divided by the total duration of exposure.

Also, the work time devoted to tasks giving rise to exposure of at least 1 "ppm" was calculated for each job. The mean weekly percentage of time with exposure to $>1$ "ppm" during the exposed period (the total duration of work with exposure $>1$ "ppm" divided by the total duration of exposure) was then calculated for each subject's whole life. The temporal variables of exposure (exposure duration, time since first exposure, and time since last exposure) were also calculated.

Finally, the existence of peak exposures $>30$ "ppm" was reported by the experts, based on work descriptions. This exposure concerned subjects who regularly siphoned, by oral suction, pure benzene (four chemists) or petrol (one mechanic and one petrol station attendant) for at least a few minutes a month.

\section{STATISTICAL ANALYSIS}

The ORs were estimated by conditional logistic regression for matched sets, with a variable number of controls per pair, with SAS procedure PHREG. ${ }^{27}$ The OR estimates are given with their corresponding $95 \%$ CIs. The means (SEMs) of the quantitative variables are given.

\section{CONFOUNDING, EFFECT MODIFICATION, AND BIAS}

In a previous analysis, ${ }^{28}$ a clear cut negative association between smoking and HCL emerged, with the ORs decreasing with increasing daily cigarette consumption, and lower ORs among current smokers than among former smokers. This finding was consistent with observations from other casecontrol studies on HCL. ${ }^{16} 17$ Smoking was therefore considered a potential confounder or effect modifier in the analysis. A history of farm work was also found to be associated with $\mathrm{HCL}$ in a previous analysis, ${ }^{28}$ and this factor was therefore also taken into account.

Because of the high proportion of prevalent cases in the study sample, the analysis has also been restricted to pairs in which the cases were diagnosed after 1984, when interferon- $\alpha$ became available for therapeutic use and resulted in a threefold reduction in mortality (about $15 \%$ of cases).

\section{Results}

COMPARABILITY OF CASES AND CONTROLS

As table 2 shows, matching resulted in satisfactory case-control comparability for age, residential area, socioeconomic status, and educational level.

\section{SMOKING, FARMING, AND HCL}

Table 3 shows the association described previously $^{28}$ between smoking and HCL and the positive association with farming. ${ }^{29}$

\section{DESCRIPTION OF EXPOSED JOBS}

The sample included 125 subjects, 34 cases (15\%), and 91 controls ( $21 \%)$, who had been exposed to benzene for at least one hour a month during one of their jobs. In that population, only two cases and five controls had been exposed to pure benzene. The other subjects were exposed to mixtures containing benzene (petrol, benzine, or non-dearomatised Stoddart solvent).

Exposures covered 252 exposed job periods, $17(7 \%)$ of which were associated with a high level of exposure and $127(50 \%)$ with a moderate level of exposure. Sixty two job periods $(25 \%)$ were assigned an exposure $>1$ "ppm" for more than three hours a week and 65 job periods (26\%) were assigned the same exposure for one to three hours a week.

Table 2 Sociodemographic and smoking characteristics of cases and controls

\begin{tabular}{|c|c|c|}
\hline & $\begin{array}{l}\text { Cases } \\
(n=226)\end{array}$ & $\begin{array}{l}\text { Controls } \\
(n=425)\end{array}$ \\
\hline $\begin{array}{l}\text { Age (mean (SEM)) } \\
\text { Residence relative to the } \\
\text { area where the hospital is } \\
\text { located }(\%) \text { : }\end{array}$ & $55 \cdot 7(0 \cdot 7)$ & $56.0(0.5)$ \\
\hline $\begin{array}{l}\text { Inside } \\
\text { Outside }\end{array}$ & $\begin{array}{l}77 \\
23\end{array}$ & $\begin{array}{l}78 \\
22\end{array}$ \\
\hline $\begin{array}{l}\text { Socioeconomic status } \\
\text { (last job held) }(\%): \\
\text { Professional, technical workers, } \\
\text { administrators, and }\end{array}$ & & \\
\hline $\begin{array}{l}\text { managers`} \\
\text { Clerical, sales, and service }\end{array}$ & $29 \cdot 7$ & $27 \cdot 3$ \\
\hline $\begin{array}{l}\text { workers } \\
\text { Production and agricultural }\end{array}$ & $24 \cdot 8$ & $26 \cdot 3$ \\
\hline $\begin{array}{l}\text { workers } \\
\text { Never employed } \\
\text { Unknown }\end{array}$ & $\begin{array}{r}44 \cdot 7 \\
0 \cdot 4 \\
0 \cdot 4\end{array}$ & $\begin{array}{r}45 \cdot 9 \\
0.0 \\
0.5\end{array}$ \\
\hline \multirow{3}{*}{$\begin{array}{l}\text { School level (highest diploma) (\%): } \\
\text { No diploma } \\
\text { Primary school } \\
\text { Junior school } \\
\text { High school or university } \\
\text { graduate }\end{array}$} & & \\
\hline & $\begin{array}{l}21 \\
32 \\
31\end{array}$ & $\begin{array}{l}18 \\
33 \\
32\end{array}$ \\
\hline & 16 & 16 \\
\hline
\end{tabular}

No significant differences existed between cases and controls *Including farm owners. 
Table 3 Association between HCL, smoking, and agriculture

\begin{tabular}{|c|c|c|c|c|}
\hline & $\begin{array}{l}\text { Cases } \\
(n=226)\end{array}$ & $\begin{array}{l}\text { Controls } \\
(n=425)\end{array}$ & OR $(95 \% C I)$ & Pvalue \\
\hline \multicolumn{5}{|l|}{ Smoking (\%): } \\
\hline Non smokers & $36 \cdot 7$ & $23 \cdot 5$ & 1.0 & $\star \star \star \star$ \\
\hline Former smokers & $34 \cdot 5$ & $34 \cdot 1$ & $0.6(0.4-0.9)$ & \\
\hline Current smokers & $24 \cdot 3$ & $38 \cdot 3$ & $0.4(0.2-0.6)$ & \\
\hline Unknown & $4 \cdot 4$ & $4 \cdot 0$ & & \\
\hline \multicolumn{5}{|c|}{ Cumulative cigarette } \\
\hline Non-smokers & $36 \cdot 7$ & 23.5 & $1.0-$ & $\star \star \star$ \\
\hline$<10$ & $19 \cdot 9$ & $16 \cdot 7$ & $0.6(0.3-1.0)$ & \\
\hline $10-23$ & $16 \cdot 4$ & $19 \cdot 1$ & $0.4(0.3-0.8)$ & \\
\hline$\geqslant 24$ & $12 \cdot 4$ & $22 \cdot 6$ & $0.3(0.2-0.5)$ & \\
\hline Unknown & $14 \cdot 6$ & $18 \cdot 1$ & -- & \\
\hline \multicolumn{5}{|l|}{ Agriculture (\%): } \\
\hline Farmers and foresters & $38 \cdot 5$ & $28 \cdot 7$ & $1 \cdot 7(1 \cdot 2-2 \cdot 5)$ & $\star \star$ \\
\hline
\end{tabular}

${ }^{\star \star P}<0.01 ;{ }^{\star \star \star} \mathrm{P}<0.001$. OR estimated with conditional logistic regression $v$ unexposed.

Table 4 shows the distribution of the main jobs classified as exposed to benzene as a function of exposure level and the duration (working time) of exposure to > 1 "ppm".

The rare cases who used pure benzene were encountered among former chemistry laboratory workers. Low level exposure was never involved, but none of the jobs resulted in exposures $>1$ "ppm" for more than three hours a week. However, peak exposures of $>1000$ "ppm" probably occurred. Employment as a histologist (not cited in table 4) also gave rise to exposure to pure benzene in 1954-6, with occasional peaks. It should be noted that the popula- tion sample did not include any former rotogravure or photogravure printers. In other words, the exposures in the printing industry were exclusively due to cleaning solvents and not to inks. No use of benzene based adhesives was found in the sample, including in the footwear industry where such adhesives were formerly in widespread use. Lastly, only two cases in the rubber industry may have resulted from benzene exposure. Both cases consisted of jobs in major rubber manufacturing corporations: one case of employment as a tyre retreader and vulcaniser from 1963 to 1973 and one of employment as a tyre retreader from 1967 to 1985 . For both cases the experts considered that their former employers had complied with the benzene replacement recommendations during the periods considered.

Most of the exposures were due to handling petrol as a fuel or degreasing agent. The mechanics showed the highest exposures encountered in the study population (12 jobs evaluated as involving mean exposure $>1$ "ppm" and 48 jobs involving exposure evaluated as $>1$ "ppm" for more than three hours a week). One former mechanic and one former petrol station attendant reported having siphoned petrol from tanks and were therefore considered to have been exposed to peaks $>30$ "ppm".

Table 4 Description of main job periods exposed to benzene in the study sample

\begin{tabular}{|c|c|c|c|c|c|c|c|c|c|c|}
\hline \multirow[b]{2}{*}{ fobs (codes) } & \multirow[b]{2}{*}{$\begin{array}{l}\text { Total in } \\
\text { category }\end{array}$} & \multicolumn{2}{|l|}{$\begin{array}{l}\text { Exposure to } \\
\text { benzene }\end{array}$} & \multicolumn{3}{|c|}{$\begin{array}{l}\text { Mean exposure over a } 40 \mathrm{~h} \\
\text { working weekf }\end{array}$} & \multicolumn{3}{|c|}{$\begin{array}{l}\text { Weekly duration of } \\
\text { exposure }>1 \text { "ppm" }\end{array}$} & \multirow[b]{2}{*}{ Peak } \\
\hline & & $\begin{array}{l}\text { All } \\
\text { benzene } \\
n(\%)\end{array}$ & $\begin{array}{l}\text { Pure } \\
\text { benzene } \\
n\end{array}$ & 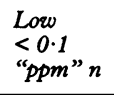 & $\begin{array}{l}\text { Medium } \\
0 \cdot 1-1 \\
" p p m " n\end{array}$ & $\begin{array}{l}\text { High } \\
>1 \text { “ } p p m \text { ” } \\
n\end{array}$ & $\begin{array}{l}\text { Low } \\
<1 \mathrm{~h} / \mathrm{w} \\
n\end{array}$ & $\begin{array}{l}\text { Medium } \\
1-3 \mathrm{~h} / \mathrm{w} \\
n\end{array}$ & $\begin{array}{l}\text { High } \\
>3 h / w \\
n\end{array}$ & \\
\hline \multicolumn{11}{|l|}{ Chemical industry: } \\
\hline Chemical sector $(351,352,353,354)^{\star}$ & 46 & $7(15)$ & 7 & - & 7 & - & 1 & 6 & - & - \\
\hline Chemical industry jobs $(0.11,0.36,7 \cdot 4) \dagger$ & 22 & $9(41)$ & 9 & - & 8 & 1 & 3 & 6 & - & 6 \\
\hline Chemists $(0 \cdot 11) \dagger$ & 5 & $4(80)$ & 4 & - & 4 & - & - & 4 & - & 1 \\
\hline Technicians $(0.36) \dagger$ & 5 & $3(60)$ & 3 & - & 2 & 1 & 3 & - & - & 5 \\
\hline Chemical processors $(7 \cdot 4) \dagger$ & 12 & $2(17)$ & 2 & - & 2 & - & - & 2 & - & - \\
\hline Supervisors $(7 \cdot 00 \cdot 60) \dagger$ & 2 & $1(50)$ & 1 & - & 1 & - & 1 & - & - & - \\
\hline \multicolumn{8}{|l|}{ Rubber industry: } & & & \\
\hline $\begin{array}{l}\text { Rubber sector }(355)^{\star} \\
\text { Rubber workers }(9 \cdot 0) \dagger\end{array}$ & 7 & $0=$ & 0 & E & $\bar{z}$ & - & E & - & 二 & E \\
\hline \multicolumn{11}{|l|}{ Footwear industry: } \\
\hline Footwear sector $(324)^{\star}$ & 12 & $2(17)$ & 0 & 2 & - & - & 2 & - & - & - \\
\hline \multirow{2}{*}{\multicolumn{11}{|c|}{ Printing: }} \\
\hline & & & & & & & & & & \\
\hline Printing sector $(382)^{\star}$ & 13 & $2(15)$ & 0 & - & 2 & - & - & 2 & - & - \\
\hline \multirow{2}{*}{\multicolumn{11}{|c|}{ Mechanics-maintenance: }} \\
\hline & & & & & & & & & & \\
\hline Mechanics: & 147 & $102(69)$ & 0 & 17 & 70 & 12 & 11 & 26 & 48 & - \\
\hline Automotive mechanics (8.43) $\dagger$ & 94 & $81(86)$ & 0 & 8 & 59 & 11 & 5 & 21 & 41 & - \\
\hline Machine mechanics (8.49) $t$ & 50 & $20(40)$ & 0 & 8 & 11 & 1 & 6 & 5 & 7 & - \\
\hline Ship mechanics $(9 \cdot 8 \dot{2}) \dagger$ & 3 & $1(33)$ & 0 & 1 & $\overline{10}$ & - & - & - & - & - \\
\hline Maintenance: & 162 & $31(19)$ & 0 & 18 & 13 & - & 18 & 7 & 4 & - \\
\hline Carriers $(9 \cdot 85) \dagger$ & 146 & $27(17)$ & 0 & 16 & 11 & - & 16 & 6 & 3 & 1 \\
\hline Earth moving operators $(9 \cdot 74)^{2}$ & 16 & $4(25)$ & 0 & 2 & 2 & - & 2 & 1 & 1 & - \\
\hline Petrol station attendants $(4 \cdot 51 \cdot 88)^{2}$ & 5 & $5(100)$ & 0 & 1 & 4 & - & 1 & $i$ & - & 1 \\
\hline \multicolumn{11}{|l|}{ Use of degreasing agents: } \\
\hline $\begin{array}{l}\text { Machining: } \\
\text { Machine tool operators (8.3) } \dagger\end{array}$ & $\begin{array}{l}150 \\
104\end{array}$ & $\begin{aligned} 11(7) \\
6(6)\end{aligned}$ & $\begin{array}{l}1 \\
0\end{array}$ & $\frac{4}{2}$ & $\begin{array}{l}5 \\
3\end{array}$ & 2 & -2 & $\mathbf{4}$ & 2 & - \\
\hline $\begin{array}{l}\text { Macnine tool operators (8.3) } \uparrow \\
\text { Fitters (8.41) } \dagger\end{array}$ & $\begin{array}{r}104 \\
42\end{array}$ & $4(10)$ & 0 & 2 & $\begin{array}{l}3 \\
1\end{array}$ & 1 & $\overline{2}$ & 1 & 1 & 三 \\
\hline \multirow{2}{*}{\multicolumn{11}{|c|}{ Electricians $(8.51,8.53,8.55,8.56$, }} \\
\hline & & & & & & & & & & \\
\hline \multicolumn{11}{|l|}{$\begin{array}{l}\text { 8.57)† } \\
\text { Paint and adhesive users: }\end{array}$} \\
\hline Painters $(9 \cdot 31,9 \cdot 39) \dagger$ & & $21(66)$ & 0 & 20 & - & - & - & - & - & - \\
\hline House painters $(9 \cdot 31) \dagger$ & 11 & $8(73)$ & 0 & 7 & - & - & - & - & - & - \\
\hline Other painters $(9 \cdot 39) \dagger$ & 21 & $13(62)$ & 0 & 13 & - & - & - & - & - & - \\
\hline \multirow{4}{*}{$\begin{array}{l}\text { Wood workers }(8 \cdot 12,8 \cdot 19,9 \cdot 54) \dagger \\
\text { Building maintenance }(9 \cdot 81,9 \cdot 59 \cdot 10 \text {, } \\
9 \cdot 59 \cdot 20) \dagger \\
\text { Plumbers }(8 \cdot 71.05) \dagger\end{array}$} & 8 & $5(63)$ & 0 & 4 & 1 & - & - & - & - & - \\
\hline & 81 & $10(12)$ & 0 & 10 & - & - & - & - & - & - \\
\hline & 27 & $5(19)$ & 0 & 4 & & - & - & 1 & - & - \\
\hline & 23 & $6(26)$ & 0 & 4 & 2 & - & 2 & 2 & - & - \\
\hline
\end{tabular}

*International standard industrial classification.

†International labour office.

$\$$ The quote marks indicate that these values are not quantitative determinations but retrospective expert estimations.

Numbers do not add to the number of exposed jobs where quantitative data were missing. 
Table 5 Association between HCL and jobs exposed to benzene

\begin{tabular}{|c|c|c|c|c|}
\hline fobs (codes) & $\begin{array}{l}\text { Cases } \\
(n=226)\end{array}$ & $\begin{array}{l}\text { Controls } \\
(n=425)\end{array}$ & $\begin{array}{l}\text { OR }(95 \% C I) \\
\text { conditional logistic } \\
\text { regression }\end{array}$ & $\begin{array}{l}\text { OR (95\% CI) } \\
\text { adjusted for smoking } \\
\text { and farming }\end{array}$ \\
\hline \multicolumn{5}{|l|}{ Chemical industry: } \\
\hline Chemical industry $(351,352,353,354)^{\star}$ & 7 & 21 & $0.6(0.3-1.5)$ & $0.5(0 \cdot 2-1 \cdot 4)$ \\
\hline Chemists and technicians $(0.11,0.36) \dagger$ & 1 & 4 & $0.4(0.1-3.9)$ & $0 \cdot 5(0 \cdot 1-4 \cdot 3)$ \\
\hline \multicolumn{5}{|l|}{ Rubber industry: } \\
\hline Rubber industry $(355)^{\star}$ & 3 & 4 & $1 \cdot 4(0 \cdot 3-6 \cdot 1)$ & $1 \cdot 5(0 \cdot 3-6 \cdot 8)$ \\
\hline Rubber workers $(9 \cdot 0) \dagger$ & 3 & 6 & $0.9(0.2-3 \cdot 7)$ & $0.9(0 \cdot 2-3.9)$ \\
\hline \multicolumn{5}{|l|}{ Footwear industry: } \\
\hline Footwear sector $(324)^{\star}$ & 1 & 7 & $0.2(0.02-1 \cdot 8)$ & $0.3(0.03-3.0)$ \\
\hline Footwear workers $(8.01,8.02) \dagger$ & i & 5 & $0.4(0.05-3.5)$ & $0.4(0.05-4.0)$ \\
\hline \multicolumn{5}{|l|}{ Printing: } \\
\hline Printing sector $(342)^{\star}$ & 3 & 5 & $1 \cdot 1(0 \cdot 3-4 \cdot 5)$ & $1 \cdot 2(0 \cdot 3-5 \cdot 3)$ \\
\hline Press operators $(9 \cdot 22) \dagger$ & 2 & 3 & $1 \cdot 1(0 \cdot 1-12 \cdot 7)$ & $1 \cdot 3(0 \cdot 1-15 \cdot 0)$ \\
\hline \multicolumn{5}{|l|}{ Jobs exposed to fuels: } \\
\hline Mechanics $(8 \cdot 43,8 \cdot 49,9 \cdot 82) \dagger:$ & 16 & 55 & $0.5(0.3-0.9)$ & $0 \cdot 6(0 \cdot 3-1 \cdot 1)$ \\
\hline Automotive mechanics $(8 \cdot 43) \dagger$ & 8 & 30 & $0.5(0.2-1.0)$ & $0.5(0 \cdot 2-1 \cdot 3)$ \\
\hline Petrol station attendants $(4 \cdot 51 \cdot 88) \dagger$ & 2 & 3 & $1 \cdot 6(0 \cdot 3-9 \cdot 4)$ & $1.9(0.3-13.9)$ \\
\hline Occasional maintenance $(9 \cdot 74,9.85) \dagger$ & 31 & 59 & $1.0(0 \cdot 6-1 \cdot 7)$ & $1 \cdot 2(0 \cdot 7-2 \cdot 1)$ \\
\hline \multicolumn{5}{|l|}{ Use of degreasing agents: } \\
\hline Machine tool operators and toolmakers $(8 \cdot 3) \dagger$ & 21 & 39 & $1.0(0.6-1.9)$ & $1 \cdot 2(0 \cdot 7-2 \cdot 3)$ \\
\hline Clock makers $(8 \cdot 42 \cdot 20,8 \cdot 42 \cdot 25) \dagger$ & 2 & 2 & $1.9(0 \cdot 3-13 \cdot 8)$ & $2 \cdot 2(0 \cdot 3-15 \cdot 8)$ \\
\hline Electricians $(8.51,8.53,8.55,8.56,8.57) \dagger$ & 16 & 33 & $1.0(0.5-1.9)$ & $1 \cdot 0(0 \cdot 5-2 \cdot 0)$ \\
\hline \multicolumn{5}{|l|}{ Use of adhesive and paints: } \\
\hline Painters $(9 \cdot 31,9 \cdot 39) \dagger$ & 4 & 8 & $0.9(0.3-3 \cdot 2)$ & $0 \cdot 8(0 \cdot 2-3 \cdot 3)$ \\
\hline Vehicle sheet metal workers $(8 \cdot 73 \cdot 70) \dagger$ & 2 & 4 & $1 \cdot 1(0 \cdot 2-6 \cdot 0)$ & $3 \cdot 2(0 \cdot 4-26 \cdot 1)$ \\
\hline Wood workers $(8 \cdot 12,8 \cdot 19,9 \cdot 54) \dagger$ & 12 & 30 & $0.7(0.3-1.4)$ & $0 \cdot 7(0.3-1 \cdot 6)$ \\
\hline Decorators $(1.62) \dagger$ & 1 & 0 & & \\
\hline Paint maintenance $(9 \cdot 82,9 \cdot 59 \cdot 10,9 \cdot 59 \cdot 20) \dagger$ & 6 & 13 & $0.9(0.3-2 \cdot 3)$ & $0.6(0.2-1.9)$ \\
\hline Plumbers $(8.71 .05) \dagger$ & 3 & 10 & $0 \cdot 6(0 \cdot 2-2 \cdot 1)$ & $1 \cdot 0(0 \cdot 3-3 \cdot 6)$ \\
\hline At least one of the above jobs & 101 & 223 & $0.7(0.5-1 \cdot 1)$ & $0.9(0.6-1 \cdot 3)$ \\
\hline
\end{tabular}

^International standard industrial classification codes for the economic sectors.

tInternational labour office codes for the jobs.

To a lesser degree, metal part degreasing and hand cleaning with petrol were also conducted by machine tool operators and electricians. The sample included only one clock maker who used benzine in small quantities.

Overall, the median for mean exposures in the population of exposed subjects was $0 \cdot 2$ "ppm".

\section{RELATION BETWEEN HCL AND BENZENE} EXPOSURE

Table 5 shows the ORs associated with the jobs or industrial sectors for which exposure was initially considered probable. None of these jobs was associated with HCL. Having held any of those jobs was associated with an OR $(95 \% \mathrm{CI})$ of $0.9(0 \cdot 6-1 \cdot 3)$ after adjustment for smoking (smoker, ex-smoker, or non-smoker) and for a history of agricultural employment (farming for at least six months).

The OR associated with all exposures to benzene together, whether or not pure, was 0.8 $(0 \cdot 5-1 \cdot 2)$, after adjustment for smoking and agricultural employment (table 6). None of the quantitative indices (maximum exposure-that is, mean exposure in the most exposed jobcumulative exposure, mean weekly frequency of exposure to $>1$ "ppm", number of hours of

Table 6 Association between HCL and benzene exposure

\begin{tabular}{|c|c|c|c|c|}
\hline & $\begin{array}{l}\text { Cases } \\
(n=226)\end{array}$ & $\begin{array}{l}\text { Controls } \\
(n=425)\end{array}$ & $\begin{array}{l}\text { OR }(95 \% C I) \\
\text { conditional logistic } \\
\text { regression }\end{array}$ & $\begin{array}{l}\text { OR (95\% CI) } \\
\text { adjusted for smoking } \\
\text { and farming }\end{array}$ \\
\hline \multicolumn{5}{|l|}{ Benzene exposure: } \\
\hline All exposures to benzene & 34 & 91 & $0.7(0.4-1.0)$ & $0.8(0.5-1 \cdot 2)$ \\
\hline Pure benzene exposure & 2 & 5 & $0 \cdot 7(0 \cdot 1-4 \cdot 0)$ & $0 \cdot 7(0 \cdot 1-4 \cdot 1)$ \\
\hline Petrol & & & $0 \cdot 8(0 \cdot 5-1 \cdot 2)$ & $0.9(0.5-1.5)$ \\
\hline \multicolumn{5}{|l|}{ Maximum exposure ("ppm"^): } \\
\hline Unexposed & 189 & 327 & 1.0 reference & - \\
\hline$<0.1$ & 12 & 35 & $0 \cdot 6(0 \cdot 3-1 \cdot 3)$ & $0.7(0.4-1.5)$ \\
\hline $0 \cdot 1-0.5$ & 12 & 27 & $0.8(0.4-1.6)$ & $0.9(0.6-2.0)$ \\
\hline$>0.5$ & 8 & 26 & $0.5(0 \cdot 2-1 \cdot 1)$ & $0 \cdot 7(0 \cdot 3-1 \cdot 7)$ \\
\hline Unknown & 5 & 10 & - & - \\
\hline \multicolumn{5}{|c|}{ Cumulative exposure ("ppm"-y): } \\
\hline Unexposed & 189 & 327 & 1.0 reference & - \\
\hline$<1$ & 15 & 39 & $0 \cdot 7(0 \cdot 4-1 \cdot 3)$ & $0.9(0.5-1.7)$ \\
\hline $1-5$ & 10 & 29 & $0.7(0.3-1.4)$ & $0 \cdot 7(0 \cdot 3-1 \cdot 7)$ \\
\hline$\geqslant 5$ & 7 & 19 & $0.5(0 \cdot 2-1 \cdot 2)$ & $0.6(0 \cdot 3-1 \cdot 7)$ \\
\hline Unknown & 5 & 11 & - & - \\
\hline \multirow{2}{*}{\multicolumn{5}{|c|}{$\begin{array}{l}\text { Mean weekly frequency of exposure to } \\
>1 \text { "ppm" (h/week): }\end{array}$}} \\
\hline & & & & \\
\hline Unexposed & 195 & 355 & 1.0 reference & - \\
\hline$<1$ & 8 & 20 & $0.7(0.3-1 \cdot 7)$ & $0.9(0.4-2 \cdot 1)$ \\
\hline $1-3$ & 12 & 19 & $1 \cdot 2(0 \cdot 6-2 \cdot 5)$ & $1.3(0.6-2.9)$ \\
\hline$>3$ & 6 & 22 & $0.4(0 \cdot 2-1 \cdot 1)$ & $0.6(0.2-1 \cdot 7)$ \\
\hline Unknown & 5 & 9 & - & - \\
\hline \multicolumn{5}{|c|}{ Lifelong total hours exposed to $>1$ "ppm" (h): } \\
\hline Unexposed & 195 & 355 & 1.0 reference & - \\
\hline$\leqslant 400$ & 10 & 19 & $1 \cdot 0(0 \cdot 5-2 \cdot 2)$ & $1 \cdot 4(0 \cdot 6-3 \cdot 2)$ \\
\hline$\leqslant 1200$ & 6 & 22 & $0.5(0.2-1 \cdot 3)$ & $0.5(0.2-1.3)$ \\
\hline$>1200$ & 10 & 20 & $0.8(0.4-1.7)$ & $1 \cdot 0(0 \cdot 4-2 \cdot 4)$ \\
\hline Unknown & 5 & 9 & & - \\
\hline Peaks > 30 "ppm" & 3 & 3 & $2 \cdot 1(0 \cdot 4-10 \cdot 7)$ & $2 \cdot 1(0 \cdot 4-11 \cdot 1)$ \\
\hline
\end{tabular}

*The quote marks indicate that these values are not quantitative determinations but retrospective expert estimations. 
Table 7 Association between HCL and benzene exposure as a function of temporal exposure characteristics

\begin{tabular}{|c|c|c|c|c|}
\hline fobs (codes) & $\begin{array}{l}\text { Cases } \\
(n=226)\end{array}$ & $\begin{array}{l}\text { Controls } \\
(n=425)\end{array}$ & $\begin{array}{l}\text { OR }(95 \% \text { CI }) \\
\text { conditional logistic } \\
\text { regression }\end{array}$ & $\begin{array}{l}\text { OR (95\% CI) } \\
\text { adjusted for smoking } \\
\text { and farming }\end{array}$ \\
\hline \multicolumn{5}{|c|}{ All exposures: } \\
\hline \multicolumn{5}{|c|}{ Time since first exposure $(y)$ : } \\
\hline Unexposed & 189 & 327 & 1.0 reference & - \\
\hline$\leqslant 25$ & 8 & 31 & $0.4(0.2-1 \cdot 0)$ & $0.5(0.2-1 \cdot 2)$ \\
\hline $26-39$ & 16 & 34 & $0.8(0.4-1.5)$ & $0.8(0.4-1.6)$ \\
\hline$\geqslant 40$ & 10 & 26 & $0.7(0.3-1.6)$ & $1 \cdot 0(0 \cdot 4-2 \cdot 1)$ \\
\hline Únknown & 3 & 7 & - & - \\
\hline \multicolumn{5}{|c|}{ Time since exposure cessation (y): } \\
\hline Unexposed & 189 & 327 & 1.0 reference & - \\
\hline$\leqslant 5$ & 11 & 30 & $0.6(0 \cdot 3-1 \cdot 2)$ & $0.6(0 \cdot 3-1 \cdot 3)$ \\
\hline 6-20 & 8 & 29 & $0.4(0 \cdot 2-1 \cdot 1)$ & $0.4(0.2-1.0)$ \\
\hline$>20$ & 15 & 32 & $0.9(0.5-1.7)$ & $1 \cdot 3(0 \cdot 7-2 \cdot 6)$ \\
\hline Unknown & 3 & 7 & - & - \\
\hline \multicolumn{5}{|c|}{ Exposure duration (y): } \\
\hline Unexposed & 189 & 327 & 1.0 reference & - \\
\hline$\geqslant 5$ & 8 & 36 & $0.4(0.2-1 \cdot 0)$ & $0.6(0.3-1 \cdot 4)$ \\
\hline $6-20$ & 16 & 27 & $1.0(0.5-1.9)$ & $1 \cdot 1(0 \cdot 5-2 \cdot 3)$ \\
\hline$>20$ & 10 & 28 & $0 \cdot 6(0 \cdot 3-1 \cdot 3)$ & $0.6(0.3-1 \cdot 4)$ \\
\hline Unknown & 3 & 7 & - & - \\
\hline \multicolumn{5}{|c|}{ Medium or high exposure: } \\
\hline \multicolumn{5}{|c|}{ Time since first exposure $(y)$ : } \\
\hline Unexposed & 201 & 362 & 1.0 reference & - \\
\hline$\leqslant 25^{\circ}$ & 4 & 16 & $0.4(0 \cdot 1-1 \cdot 2)$ & $0.5(0 \cdot 1-1 \cdot 8)$ \\
\hline $26-39$ & 10 & 20 & $0.9(0.4-2.0)$ & $1.0(0.4-2 \cdot 3)$ \\
\hline$\geqslant 40$ & 6 & 18 & $0.6(0 \cdot 2-1 \cdot 7)$ & $0 \cdot 8(0 \cdot 3-2 \cdot 3)$ \\
\hline Únknown & 5 & 9 & - & - \\
\hline \multicolumn{5}{|c|}{ Time since exposure cessation $(y)$ : } \\
\hline Unexposed & 201 & 362 & 1.0 reference & - \\
\hline$\leqslant 5$ & 6 & 16 & $0.5(0.2-1.5)$ & $0 \cdot 6(0 \cdot 2-1 \cdot 7)$ \\
\hline $6-20$ & 6 & 17 & $0.6(0.2-1 \cdot 6)$ & $0 \cdot 6(0 \cdot 2-1 \cdot 7)$ \\
\hline$>20$ & 8 & 21 & $0.8(0.3-1.8)$ & $1 \cdot 3(0 \cdot 5-3 \cdot 2)$ \\
\hline Unknown & 5 & 9 & - & - \\
\hline \multicolumn{5}{|c|}{ Exposure duration $(y)$ : } \\
\hline Unexposed & 201 & 362 & 1.0 reference & - \\
\hline$\geqslant 5$ & 7 & 22 & $0.6(0 \cdot 2-1 \cdot 4)$ & $0.9(0.3-2 \cdot 2)$ \\
\hline $6-20$ & 7 & 21 & $0.6(0 \cdot 2-1 \cdot 4)$ & $0.7(0 \cdot 3-1 \cdot 7)$ \\
\hline$>20$ & 6 & 10 & $0.9(0.3-2.6)$ & $1 \cdot 0(0 \cdot 3-3 \cdot 2)$ \\
\hline Unknown & 5 & 10 & - & - \\
\hline
\end{tabular}

work with exposure to $>1$ "ppm" throughout life) enabled an OR significantly $>1$ to be found for the highest exposures. No trend towards an increase was found. The highest exposures reported in the study population were relatively low: the mean exposures estimated for the most exposed jobs were never $>1$ "ppm" and the cumulative exposures were never $>45$ "ppm"-years. Benzene exposure peaks $>30$ "ppm" were only estimated for three cases and three controls.

There was no evidence of an association with any of the temporal variables, time since first exposure, time since the end of exposure, and duration of exposure (table 7). Moreover, if only those exposures occurring at least five years before diagnosis are considered, the ORs remain close to unity (OR $0.8(0.5-1.2)$ for benzene exposure irrespective of exposure source or level).

The data available to the experts were insufficient to enable assessment of the exposure of painters before the dearomatisation of the mineral spirits used in the paint trade. The analysis in table 6 was thus repeated with exposure values 10- then 100-fold greater than the initial levels for painters. The estimated ORs remained close to 1 . No association or increasing trend was detected, although subject distribution as a function of exposure level varied substantially from estimation to estimation.

Restriction of the analysis to non-smokers and adjustment on the pack-years variable (rather than on smoker, ex-smoker, or nonsmoker) yielded similar results. Restriction of subjects to those never having farmed, or to those from regions in which little agriculture is practised had no impact on the results. Similarly, no change in the results was found when the population was restricted to those taken into hospital after 1984.

\section{Discussion}

In this study comparing $226 \mathrm{HCL}$ cases with 425 matched controls, exposure to benzene was not associated with a risk of HCL. No trend towards an increase in $\mathrm{OR}$ with increasing exposure, percentage of time exposed to $>1$ "ppm", or duration of exposure was found. No finding indicated any particular risk period when the ORs associated with the time since the first or last exposure were examined. The results based on several variables independently describing benzene exposure agreed. ${ }^{1}$ The dichotomous variable and the duration of exposure were generated without the quantitative data. ${ }^{2}$ The jobs involving benzene exposure were decided before and not as a function of the results of the evaluation. ${ }^{3}$ The quantitative evaluation may have resulted in erroneous classification but the highest exposures (and the most easily assessed) were still not associated with a high OR.

Due to the rarity of the disease, retrospective recruitment was conducted. For practical reasons, the study only examined living cases. If benzene exposure is related to duration of survival, this design could miss an effect. However, the results were unchanged when the analysis was restricted to pairs in which the cases were diagnosed after 1984, when survival was threefold higher because interferon- $\alpha$ became available for therapeutic use. Replacement of 
non-responding controls by other eligible controls did not seem to induce a bias as estimates were very similar when analysis was restricted to pairs in which the controls were unreplaced.

The order of magnitude of the exposures obtained for the various job categories with the study classification system are in line with the published data. ${ }^{152}$ Classification errors in exposure would probably have modified the ORs of the various categories to a limited extent without showing an association. This was in fact found with the painter exposure estimations: exposures were increased 100-fold without any change in the conclusions of the analysis. The interview non-response rate was comparable for cases $(7 \cdot 1 \%)$ and controls $(5 \cdot 2 \%)$.

It would therefore seem improbable that the absence of association could be totally explained by classification errors. It is, however, impossible to exclude illicit benzene use, unknown to the actual users, after prohibition of that chemical. Such exposures would have been overlooked by the analysis. Yet, it is striking that the authors' evaluation only assigns two subjects to an estimated cumulative exposure $>40 \mathrm{ppm}$-years, the upper limit of the lowest exposure category in the United States Pliofilm cohort. ${ }^{6}{ }^{30}$ The risk of leukaemia (mainly acute myeloid leukaemia) has been established for higher exposures. ${ }^{17}$ The present study population did not include any of the jobs for which high exposures have been reported: no rotogravure or photogravure printers, no use of rubber dissolving adhesives, no chemical industry workers involved in organic syntheses, no rubber industry workers who had used benzene. Aksoy's cases of HCL were exposed to adhesives incorporating benzene. ${ }^{31}$ The study by Oleske et al $^{16}$ (45 cases and 134 controls) showed a significant association between HCL and the use of petroleum products, irrespective of product type (OR 3.1 (1.5-6.4)). Staines and Cartwright $^{17}$ (50 cases and 95 controls) reported comparable results with ORs of $2 \cdot 1$ $(0 \cdot 9-5 \cdot 0)$ for use of petroleum products and $2 \cdot 0$ $(0 \cdot 5-8 \cdot 0)$ for use of benzene.

In conclusion, no association was found between HCL and benzene exposure, at the low levels experienced by the study subjects employed during the 1940s-80s in France. However, this finding does not exclude a possible association between high-level exposure and the disease. The high OR, albeit for a few subjects, associated with peak exposures $>30$ "ppm" would be compatible with that hypothesis. However, more generally, $\mathrm{HCL}$ was not found in the numerous cohorts of petrochemical workers and petrol station employees. ${ }^{15}$

This study was supported by the French Ministère de la Recherche et de la Technologie, the Caisse Régionale d'Assurance Maladie de l'Ile de France, and the Ministère chargé de l'Enseignement Supérieur. We thank Drs Bauters, Bayle, Blanc, Boasson, Broustet, Coiffier, Gardais, Gardembas, Fiere, Foussard, Guerci, Guilhot, Harousseau, Leporrier, Le Prisé, Malinvaud, Oberling, Pris, Renoux, Troussard, Schved, Streiff, Thyss, Tilly, and Walter, haematologists, for their help in the identification and recruitment of cases. We thank the in the identification and recruitment of cases. We thank the
heads of the departments where the controls were collected: Drs Ordain, Asencio, Ballanger, Bazin, Besse, Brissot, Clarac, Devulder, Dubernard, Duquennoy, Durandeau, Ferrand, Gevulder, Dubernard, Duquennoy, Durandeau, Ferrand, Thomine, Toubol, Vignon, and Ziegler.
We are also indebted to Dr Victoria Mora, occupational health physician, who conducted most of the specific interviews. We are grateful to AG Mullarky for his skillful translation of the manuscript.

1 International Agency for Research on Cancer. LARC monographs on the evaluation of the carcinogenic risk of chemicals to humans. Some industrial chemicals and dyestuffs, vol 29. Lyon, France: IARC, 1982.

2 Vigliani EC, Forni A. Benzene and leukemia. Environ Res 1976;11:122-7.

3 Aksoy M. Leukemia in workers due to occupational exposure to benzene. Clin Sci 1977;12:3-14.

4 Infante PF, Rinsky RA, Wagoner JK, Young RJ Leukaemia in benzene workers. Lancet 1977;2:76-8.

5 Rinsky RA, Young RJ, Smith AB. Leukemia in benzene workers. Am f Ind Med 1981;2:217-45.

6 Rinsky RA, Smith AB, Hornung R, Filloon TG, Young RJ, Okun AH, Landrigan PJ. Benzene and leukemia. An epidemiological risk asssessment. $N$ Engl $₹$ Med 1987;16: 1044-50.

7 Austin H, Delzell E, Cole P. Benzene and leukemia-a review of the literature and a risk assessment. $\mathrm{Am} \mathrm{f}$ Epidemiol 1988;127:419-39.

8 Lamm SH, Walters AS, Wilson R, Byrd DM, Grunwald H. Consistencies and inconsistencies underlying the quantitative assessment of leukemia risk from benzene expotative assessment of leukemia risk from be
sure. Environ Health Perspect 1989;82:289-97.

9 McMichael AJ, Spirtas R, Kupper LL, Gamble JF. Solvent exposure and leukemia among rubber workers: an epidemiologic study. F Occup Med 1975;17:234-9.

10 Arp EW, Wolf PH, Checkoway H. Lymphocytic leukemia and exposures to benzene and other solvents in the rubber industry. F Occup Med 1983;25:598-602.

11 Checkoway $H$, Wilcosky $T$, Wolf $P$, Tyroler $H$. An evaluation of the associations of leukemia and rubber industry solvents exposures. Am f Ind Med 1984;5:239-49.

12 Savitz DA, Moure R. Cancer among oil refinery workers. A review of epidemiologic studies. F Occup Med 1984;26: 662-70.

13 Harrington JM. Health experience of workers in the petroleum manufacturing and distribution industry: a review of the literature. Am $\mathcal{F}$ Ind Med 1987;12:475-97.

14 Wong O, Raabe GK. Critical review of cancer epidemiology in petroleum industry employees, with a quantitative meta-analysis by cancer site. Am f Ind Med 1989;15: 283-310.

15 International Agency for Research on Cancer. LARC monographs on the evaluation of the carcinogenic risk of chemicals to humans. Occupational exposures in petroleum refining; crude oil and major petroleum fuels, vol 45. Lyon, France: IARC, 1989.

16 Oleske D, Golomb HM, Farber MD, Levy PS. A case-control inquiry into the etiology of hairy cell leukemia. $A m \mathcal{F}$ Epidemiol 1985;121:675-83.

17 Staines A, Cartwright RA. Hairy cell leukaemia: descriptive epidemiology and a case-control study. $\mathrm{Br} \mathcal{F}$ Haematol 1993;85:714-7.

18 Flandrin $G$, Collado $S$. Is male predominance in hairy cell leukaemia related to occupational exposure to ionizing radiation, benzene, and other solvents? $\mathrm{Br} \mathcal{f}$ Haematol 1987;67:119-20.

19 International standard classification of occupations, revised edition. Geneva: International Labour Office, 1968.

20 International standard industrial classification of all economic activities. New York: United Nations, 1975.

21 Clavel J, Glass DC, Cordier S, Hémon D. Standardization in the retrospective evaluation by experts of occupational exposure to organic solvents in a population-based casecontrol study. Int $\mathcal{F}$ Epidemiol 1993:22(suppl 2):s121-6.

22 International Agency for Research on Cancer. LARC monographs on the evaluation of the carcinogenic risk of chemicals to humans. Some organic solvents, resin monomers, pigments and occupational exposures in paint manufacture and painting, vol 47. Lyon, France: IARC, 1989.

23 Jayjock MA, Levin L. Health hazards in a small automotive body repair shop. Ann Occup Hyg 1984;28:19-29.

24 Levery G, Ciccolella A, Wagner C, Lanco P, Roedel MC Stempfer JC. Evaluation du risque lié à l'exposition au benzène chez les mécaniciens de garage. Arch Mal Prof benzene chez les

25 Machefer J, Bidron P, Guignier PM. Exposition aux hydrocarbures benzeniques des carburants automobiles chez les mécaniciens et les pompistes. Arch Mal Prof 1990;51 $89-94$.

26 Nordlinder R, Ramnas $O$. Exposure to benzene at different work places in Sweden. Ann Occup Hyg 1987;31:345-55.

27 Ying SO. PROC PHREG: a procedure for Cox's proportional hazards regression analysis. Cary, NC: SAS Institute, 1991.

28 Clavel J, Mandereau L, Cordier S, Le Goaster C, Hémon D, Conso F, Flandrin G. Hairy cell leukaemia, occupation and smoking. Br $₹$ Haematol 1995;91:154-61.

29 Clavel J, Hémon D, Mandereau L, Delemotte B, Severin F, Flandrin G. Farming, pesticide use, and hairy-cell F, Flandrin G. Farming, pesticide use, and hairy-cel

30 Wong O. Risk of acute myeloid leukemia and multiple myeloma in workers exposed to benzene. Occup Environ Med 1995;52:380-4.

31 Aksoy $M$. Chronic lymphoid leukaemia and hairy cell leukaemia due to chronic exposure to benzene: report of three cases. Br $\mathcal{F}$ Haematol 1987;66:209-11. 